\title{
Reductive catabolism of pyrimidine bases by Pseudomonas stutzeri
}

\author{
GuORONG XU and Thomas P. WeST* \\ Olson Biochemistry Laboratories, Department of Chemistry, South Dakota State University, Brookings, \\ South Dakota 57007, USA
}

(Received 5 May 1992; revised 6 July 1992; accepted 13 July 1992)

\begin{abstract}
Pyrimidine base catabolism in Pseudomonas stutzeri ATCC 17588 was investigated and was found to occur by means of the reductive pathway. Pyrimidine bases and their respective reductive pathway catabolic products could serve as nitrogen sources for growth of $\boldsymbol{P}$. stutzeri. Activities of the three enzymes associated with the reductive pathway of pyrimidine catabolism were detected in cells of $\boldsymbol{P}$. stutzeri. The initial enzyme of the reductive pathway, dihydropyrimidine dehydrogenase, utilized NADH as its nicotinamide cofactor. Cells grown on pyrimidine bases as nitrogen sources contained elevated dehydrogenase activity relative to those grown on ammonium sulphate as nitrogen source. Activities of the second and third reductive pathway enzymes, dihydropyrimidinase and $\boldsymbol{N}$-carbamoyl- $\boldsymbol{\beta}$-alanine amidohydrolase, respectively, were also affected by growth conditions. If pyrimidine or dihydropyrimidine bases served as nitrogen sources, increases in the levels of these enzymes were observed compared to their activities determined when the nitrogen source was ammonium sulphate.
\end{abstract}

\section{Introduction}

Catabolism of the pyrimidine bases uracil and thymine as a source of nitrogen has been shown to occur in prokaryotes. There are two different pyrimidine catabolic pathways (Vogels \& van der Drift, 1976). Oxidative catabolism of uracil results in the formation of urea and malonic acid while thymine is degraded to 5-methylbarbituric acid (Hayaishi \& Kornberg, 1952). Strains of Nocardia and Mycobacterium degrade pyrimidines in this way (Hayaishi \& Kornberg, 1952; Lara, 1952), as does the enteric bacterium Enterobacter aerogenes (Patel \& West, 1987). The second pathway of pyrimidine catabolism is a reductive pathway (Vogels \& van der Drift, 1976). This pathway consists of three enzymic steps. The initial step is catalysed by dihydropyrimidine dehydrogenase (EC 1.3.1.2), which converts uracil and thymine to dihydrouracil and dihydrothymine, respectively. Dihydropyrimidinase (EC 3.5.2.2) is responsible for the second step, in which $N$-carbamoyl- $\beta$-alanine and $N$-carbamoyl- $\beta$-aminoisobutyric acid are formed from dihydrouracil and dihydrothymine, respectively. This enzyme, also called hydantoinase, may prove vital in the development of large-scale bioreactor systems for the inexpensive production of $\mathrm{D}$-amino acids from hydantoins (Morin et al., 1986; Chevalier et al., 1989). The final reaction of the reductive pathway is catalysed by

\footnotetext{
* Author for correspondence. Tel. (605) 6886171 ; fax (605) 6886295.
}

$N$-carbamoyl- $\beta$-alanine amidohydrolase (EC 3.5.1.6). This enzyme produces $\beta$-alanine or $\beta$-aminoisobutyric acid from their respective $N$-carbamoyl derivatives. The reductive pathway operates in a number of prokaryotes including Clostridium uracilicum (Campbell, 1957), Acidovorax facilis (Kramer \& Kaltwasser, 1969), Salmonella typhimurium (West et al., 1985), Pseudomonas aeruginosa (Kim \& West, 1991) and Pseudomonas chlororaphis (West, 1991b).

Pyrimidine catabolism in the fluorescent pseudomonads has only recently been examined in detail. The fluorescent pseudomonad Pseudomonas stutzeri is now recognized to be of clinical significance in humans. Of particular importance is the role of $P$. stutzeri as an opportunistic pathogen during the treatment of human cancer with such chemotherapeutic agents as 5-fluorouracil. Considering this clinical relevance, catabolism of pyrimidine bases was studied in the type strain of $P$. stutzeri.

\section{Methods}

Strain and growth media. Pseudomonas stutzeri ATCC 17588 (Stanier et al., 1966) was the strain utilized in this study. The minimal medium was prepared as described previously (West, 1989).

Growth conditions. Liquid medium cultures were used to investigate the ability of the strain to utilize pyrimidine bases and their catabolic products as nitrogen sources. Uracil, dihydrouracil, cytosine, thymine, dihydrothymine or $\beta$-alanine was included in the medium as nitrogen 
source at a concentration of $0.2 \%$. Glucose or succinate was present in the medium as a carbon source at a concentration of $0.4 \%$. Each liquid culture was grown with aeration at $30^{\circ} \mathrm{C}$ on a rotary shaker $(200$ r.p.m.). Growth was measured spectrophotometrically at $600 \mathrm{~nm}$. Bacterial cell concentration (cells $\mathrm{ml}^{-1}$ ) was estimated from a previously determined $\mathrm{OD}_{600}$ versus cell concentration calibration curve.

When studying whether the elevation of pyrimidine catabolic enzyme activities that occurs in cells grown on succinate minimal medium containing thymine as sole nitrogen source was dependent upon protein synthesis, $P$. stutzeri was first grown in $500 \mathrm{ml}$ of succinate minimal medium containing $0.4 \%$ ammonium sulphate until midexponential phase. After collecting and washing the cells, they were resuspended in succinate minimal medium containing $0.2 \%$ thymine as sole nitrogen source. Immediately, this culture was divided into two cultures of equal volume and $0.1 \mathrm{mg}$ chloramphenicol ml-1 was added to only one of these separate cultures. Both cultures were grown at $30^{\circ} \mathrm{C}$ for $4 \mathrm{~h}$ and then harvested.

Preparation of cell extracts. Cells from $250 \mathrm{ml}$ cultures were used to measure the pyrimidine reductive catabolic enzyme activities of $\boldsymbol{P}$. stutzeri. Once grown to the late exponential phase, the cells were collected by centrifugation at $10400 \mathrm{~g}$ at $4{ }^{\circ} \mathrm{C}$ for $20 \mathrm{~min}$. The cells were washed and suspended in $20 \mathrm{mM}$-Tris/ $\mathrm{HCl}$ buffer, $\mathrm{pH} 7 \cdot 5$, containing $1 \mathrm{~mm}$-EDTA and $1 \mathrm{~mm}$-2-mercaptoethanol. The suspended cells were sonically disrupted at maximum power for a total of $5 \mathrm{~min}$ ( $30 \mathrm{~s}$ bursts). The extract was centrifuged at $10900 \mathrm{~g}$ for $30 \mathrm{~min}$ at $4^{\circ} \mathrm{C}$. The cell-free extract was dialysed overnight at $4{ }^{\circ} \mathrm{C}$ against 1 litre of the sonication buffer.

Enzyme assays. The three reductive pathway enzyme activities of pyrimidine catabolism were assayed at $30^{\circ} \mathrm{C}$. Dihydropyrimidine dehydrogenase was assayed using a reaction mixture that contained (in $1 \mathrm{ml}$ ) $0.1 \mathrm{M}$-Tris/HCl buffer, pH 7.5, 0.2 mM-NADH, $1 \mathrm{mM}$-uracil and cell-free extract. It was assayed by monitoring the formation of $\mathrm{NAD}^{+}$ from NADH at $340 \mathrm{~nm}$ over a $10 \mathrm{~min}$ period using a molar absorptivity of $6.22 \times 10^{3} \mathrm{M}^{-1} \mathrm{~cm}^{-1}$ (Hunninghake \& Grisolia, 1965).

Dihydropyrimidinase activity was determined using a colorimetric assay for $N$-carbamoyl- $\beta$-alanine (West et al., 1982). The reaction mixture contained (in $1 \mathrm{ml}$ ) $0.1 \mathrm{M}$-Tris/ $\mathrm{HCl}$ buffer, $\mathrm{pH} 7.5,10 \mathrm{~mm}$ $\mathrm{MgCl}_{2}, 1 \mathrm{~mm}$-dihydrouracil and cell-free extract. The mixture was assayed over a $30 \mathrm{~min}$ period. At various intervals, $1 \mathrm{ml}$ of the colour mix of West et al. (1982) was added directly to the assay tubes to halt the reaction. Following colour mix addition, the tubes were capped with marbles and placed in a $70^{\circ} \mathrm{C}$ water-bath under fluorescent lighting for $2 \mathrm{~h}$. The absorbance of each assay tube was determined at $466 \mathrm{~nm}$ and activity was derived using an experimentally calculated absorption coefficient.

$N$-carbamoyl- $\beta$-alanine amidohydrolase activity was assayed by following the release of ammonium ions during the reaction. The assay

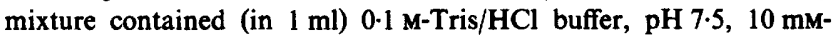
$\mathrm{MgCl}_{2}, 1 \mathrm{mM}-N$-carbamoyl- $\beta$-alanine and cell-free extract. The reaction was allowed to proceed over a $30 \mathrm{~min}$ period and terminated by addition of $5 \%(\mathrm{w} / \mathrm{v})$ trichloroacetic acid $(0.1 \mathrm{ml})$. The resulting precipitate was removed by centrifugation and the supernatant was assayed for ammonium ion formation using glutamate dehydrogenase (Tamaki \& Mizutani, 1987). Supernatant $(0.5 \mathrm{ml})$ was added to a mixture $(0.52 \mathrm{ml})$ containing $0.1 \mathrm{M}-\mathrm{Tris} / \mathrm{HCl}$ buffer, $\mathrm{pH} 8.0,0.4 \mathrm{M}-$ potassium bicarbonate, $0.01 \mathrm{M}-2$-oxo-glutarate and $0.24 \mathrm{~mm}-\mathrm{NADH}$. After the initial absorbance at $365 \mathrm{~nm}$ of the mixture was determined, 12 units of glutamate dehydrogenase were added. After incubation at room temperature for $1 \mathrm{~h}$, the absorbance at $365 \mathrm{~nm}$ was once again measured. The difference in absorbance at $365 \mathrm{~nm}$ indicates the ammonium ion concentration present in the original supernatant (Tamaki \& Mizutani, 1987).
Protein was determined by the method of Bradford (1976) with lysozyme as the standard protein. Specific activity is expressed as nmol substrate utilized or product formed $\mathrm{min}^{-1}(\mathrm{mg} \text { protein })^{-1}$. All values represented the mean of three separate determinations that were within one standard deviation.

Chemicals. All biochemicals were purchased from Sigma. The source of glutamate dehydrogenase was Boehringer Mannheim. Dialysis tubing was obtained from Spectrum.

\section{Results}

The aim of this study was to prove that the reductive pathway of pyrimidine base catabolism was operating in $P$. stutzeri ATCC 17588 . The ability of this pseudomonad to utilize pyrimidines and their respective reductive pathway catabolic products as sole sources of nitrogen in a succinate-containing medium was examined (Table 1). The data presented shows that $P$. stutzeri is capable of

\section{Table 1. Growth of $P$. stutzeri ATCC 17588 on pyrimidines and their reductive catabolic products}

Pseudomonad cells were grown at $30^{\circ} \mathrm{C}$ for $72 \mathrm{~h}$ in a succinate minimal medium with a $0.2 \%$ (w/v) concentration of each nitrogen source. Data are the average of two separate determinations that were reproducible within $\pm 10 \%$. Control cultures of minimal medium or a succinate minimal medium minus a nitrogen source contained $4.4 \times 10^{8}$ cells ml ${ }^{-1}$ or $1.6 \times 10^{6}$ cells ml $^{-1}$, respectively, after $72 \mathrm{~h}$ at $30^{\circ} \mathrm{C}$.

\begin{tabular}{lc}
\hline \hline $\begin{array}{c}\text { Nitrogen } \\
\text { source }\end{array}$ & $\begin{array}{c}10^{-8} \times \text { No. of } \\
\text { cells ml-1 }\end{array}$ \\
\hline Uracil & 8.4 \\
Dihydrouracil & $4 \cdot 0$ \\
$\beta$-Alanine & $3 \cdot 7$ \\
Thymine & 4.5 \\
Dihydrothymine & 4.9 \\
$\beta$-Aminoisobutyric acid & 3.2 \\
\hline \hline
\end{tabular}

\section{Table 2. Nicotinamide cofactor specificity of P. stutzeri dihydropyrimidine dehydrogenase}

Cell-free extracts were prepared from cells grown at $30^{\circ} \mathrm{C}$ in succinate minimal medium containing either $0.2 \%$ uracil or thymine as nitrogen source. Dihydropyrimidine dehydrogenase activity was measured under assay conditions where the enzyme substrate and nicotinamide cofactor were present at respective concentrations of $1 \mathrm{mM}$ and $0.2 \mathrm{mM}$. Each value is the mean of three separate determinations (numbers in parentheses represent standard deviations).

\begin{tabular}{|c|c|c|c|}
\hline \multirow{2}{*}{$\begin{array}{l}\text { Nitrogen } \\
\text { source }\end{array}$} & \multirow{2}{*}{$\begin{array}{l}\text { Enzyme } \\
\text { substrate }\end{array}$} & \multicolumn{2}{|c|}{$\begin{array}{c}\text { Specific activity } \\
{\left[\mathrm{nmol} \min ^{-1}(\mathrm{mg} \text { protein })^{-1}\right] \text { with: }}\end{array}$} \\
\hline & & NADH & NADPH \\
\hline Uracil & Uracil & $0.519(0.143)$ & $0.028(0.002)$ \\
\hline Uracil & Thymine & $0.404(0.115)$ & $0.034(0.017)$ \\
\hline Thymine & Uracil & $1.65 \quad(0.290)$ & $0.028(0.003)$ \\
\hline Thynine & Thymine & $2.31 \quad(0.530)$ & $0.036(0.006)$ \\
\hline
\end{tabular}


Table 3. Effect of nitrogen source and carbon source on pyrimidine catabolic enzyme activities in $P$. stutzeri

Growth conditions and enzyme assays were as described in Methods. Specific activity values given are means of three separate determinations (numbers in parentheses represent standard deviations).

\begin{tabular}{|c|c|c|c|c|}
\hline \multirow[b]{2}{*}{$\begin{array}{l}\text { Nitrogen } \\
\text { source }\end{array}$} & \multirow[b]{2}{*}{$\begin{array}{l}\text { Carbon } \\
\text { source }\end{array}$} & \multicolumn{3}{|c|}{$\begin{array}{c}\text { Specific activity } \\
{\left[\mathrm{nmol} \mathrm{min}^{-1}(\mathrm{mg} \text { protein })^{-1}\right] \text { of: }}\end{array}$} \\
\hline & & $\begin{array}{c}\text { Dihydro- } \\
\text { pyrimidine } \\
\text { dehydrogenase }\end{array}$ & $\begin{array}{c}\text { Dihydro- } \\
\text { pyrimidinase }\end{array}$ & $\begin{array}{c}N \text {-Carbamoyl- } \\
\beta \text {-alanine } \\
\text { amidohydrolase }\end{array}$ \\
\hline Ammonium sulphate & Succinate & $0.030(0.009)$ & $0.044(0.010)$ & $0.051(0.018)$ \\
\hline Uracil & Succinate & $0.519(0.143)$ & $0.725(0.081)$ & $0.683(0.054)$ \\
\hline Thymine & Succinate & $1.65 \quad(0.290)$ & $0.610(0.021)$ & $0.903(0.116)$ \\
\hline Cytosine & Succinate & $0.298(0.011)$ & $0.862(0.090)$ & $0.548(0.022)$ \\
\hline Dihydrouracil & Succinate & $0.084(0.017)$ & $1.24(0.050)$ & $1.28 \quad(0.082)$ \\
\hline Dihydrothymine & Succinate & $0.086(0.011)$ & $6.42 \quad(0.935)$ & $1.47 \quad(0.295)$ \\
\hline$\beta$-Alanine & Succinate & $0.075(0.005)$ & $0.050(0.008)$ & $0.143(0.036)$ \\
\hline Ammonium sulphate & Glucose & $0.022(0.012)$ & $0.033(0.011)$ & $0.083(0.011)$ \\
\hline Uracil & Glucose & $0.635(0.180)$ & $0.420(0.025)$ & $0.486(0 \cdot 148)$ \\
\hline Thymine & Glucose & $0.287(0.044)$ & $0.797(0.043)$ & $0.789(0.106)$ \\
\hline Cytosine & Glucose & $0.257(0.013)$ & $0.577(0.095)$ & $0.451(0.046)$ \\
\hline Dihydrouracil & Glucose & $0.066(0.007)$ & $1.53 \quad(0 \cdot 170)$ & $1.56 \quad(0 \cdot 108)$ \\
\hline Dihydrothymine & Glucose & $0.099(0.016)$ & $3.27 \quad(0.053)$ & $1.38 \quad(0.152)$ \\
\hline$\beta$-Alanine & Glucose & $0.018(0.048)$ & $0.061(0.007)$ & $0 \cdot 121(0 \cdot 098)$ \\
\hline
\end{tabular}

utilizing these compounds as nitrogen sources. Uracil appeared to sustain the highest level of pseudomonad growth while the other nitrogen sources supported bacterial growth roughly equivalently (Table 1). In particular, the increased bacterial growth on uracil relative to dihydrouracil could be attributed to uracil having a greater cell membrane permeability than dihydrouracil. This would seem to be indicated by the slower cell growth on dihydrouracil (generation time $480 \mathrm{~min}$ ) as nitrogen source compared to uracil (generation time $274 \mathrm{~min}$ ).

Prior to determining the activities of the pyrimidine catabolic enzymes, it was first necessary to learn which nicotinamide cofactor was required by dihydropyrimidine dehydrogenase of $P$. stutzeri for maximal activity. In pyrimidine-grown cells, it would appear that NADH is the nicotinamide cofactor for the dehydrogenase regardless of whether uracil or thymine served as the enzyme substrate (Table 2). Subsequently, this enzyme was assayed using $\mathrm{NADH}$.

Initially, the pyrimidine reductive catabolic pathway enzyme activities were assayed to learn if they were active in extracts prepared from cells grown on minimal medium. As seen from Table 3, all three enzyme activities were present, albeit at low levels, in these extracts. Next, the effect of growth conditions on the activities of the three reductive pathway enzymes of $P$. stutzeri was determined (Table 3). Growth on the pyrimidine bases uracil, thymine or cytosine as sole nitrogen sources increased dihydropyrimidine dehydrogenase activity (Table 3 ). The second enzyme of the pathway was also influenced by growth conditions. Growth on its substrates dihydrothymine and dihydrouracil as sole nitrogen sources resulted in at least a 28 -fold increase of dihydropyrimidinase activity (Table 3). Either uracil or thymine as a nitrogen source also increased this enzyme activity by at least 13 -fold (Table 3 ). Both the pyrimidine and dihydropyrimidine bases tested as nitrogen sources increased the activity of the third reductive pathway enzyme, $N$-carbamoyl- $\beta$-alanine amidohydrolase, severalfold (Table 3). In addition, dihydropyrimidine dehydrogenase and dihydropyrimidinase activities were affected by the nature of the carbon source, but this was observed to be nitrogensource-dependent. When thymine or $\beta$-alanine served as a nitrogen source, dihydropyrimidine dehydrogenase activity was at least 5-fold or 4-fold higher, respectively, in succinate-grown cells than in glucose-grown cells (Table 3). Similarly, dihydropyrimidinase activity was nearly double in succinate-grown cells relative to glucosegrown cells if either uracil or dihydrothymine was the nitrogen source (Table 3 ). It is not clear why glucose has a repressive effect upon the levels of both enzymes only when specific nitrogen sources are utilized by the cells. From the above findings, it appeared that the reductive pathway catabolic enzyme activities are more strongly influenced by nitrogen source than by carbon source.

To determine if the reductive pathway enzymes are 
Table 4. Regulation of pyrimidine catabolic enzyme synthesis in P. stutzeri

Cells were grown at $30^{\circ} \mathrm{C}$ in succinate minimal medium, washed, resuspended in succinate minimal medium with thymine as sole nitrogen source in the presence or absence of chloramphenicol $\left(\mathrm{Cm} ; 0 \cdot 1 \mathrm{mg} \mathrm{ml}^{-1}\right)$, and subsequently collected after $4 \mathrm{~h}$. Cell-free extracts were prepared and then assayed for the catabolic enzyme activities as described in Methods. Specific activity values are means of three separate determinations (numbers in parentheses represent standard deviations).

\begin{tabular}{lcc}
\hline \hline & \multicolumn{1}{c}{$\begin{array}{c}\text { Specific activity } \\
\left.\text { Enmol } \min ^{-1}(\mathrm{mg} \text { protein })^{-1}\right]\end{array}$} \\
\cline { 2 - 3 } \multicolumn{1}{c}{ Enzyme } & $+\mathrm{Cm}$ & $-\mathrm{Cm}$ \\
\hline Dihydropyrimidine dehydrogenase & $0.060(0.004)$ & $1.41(0.161)$ \\
Dihydropyrimidinase & $0.062(0.010)$ & $0.630(0.122)$ \\
$N$-Carbamoyl- $\beta$-alanine amidohydrolase & $0.062(0.012)$ & $1.06(0.066)$ \\
\hline \hline
\end{tabular}

regulated at the level of gene expression, the following experiment was done to determine whether the increase in their enzyme activities was dependent upon protein synthesis. Pseudomonad cells were grown in a succinate minimal medium containing ammonium sulphate as a nitrogen source, collected, washed and resuspended into minimal medium containing thymine as nitrogen source. After this thymine-containing culture was divided into two cultures of equal volume, the prokaryotic proteinsynthesis inhibitor chloramphenicol was added to only one of these cultures. Following $4 \mathrm{~h}$ of rotary shaking, the cells from each culture were processed to determine how each reductive pathway enzyme activity was affected. As can be seen in Table 4, chloramphenicol treatment resulted in low catabolic enzyme activities being detected. These activities were similar to those found in cells grown on ammonium sulphate (Table 3 ). When the protein synthesis inhibitor was absent, a significant increase in each enzyme activity occurred (Table 4). The results indicate that this rise in activity was dependent upon ongoing protein synthesis. One could conclude that the reductive pathway of pyrimidine catabolism in $P$. stutzeri ATCC 17588 is subject to regulation at the level of gene expression.

\section{Discussion}

Pyrimidine base catabolism was investigated in $P$. stutzeri ATCC 17588 and it was confirmed that the reductive pathway was operating in this pseudomonad. This pathway consists of three enzymic steps culminating in the release of ammonia and $\beta$-alanine or $\beta$-aminoisobutyric acid from uracil or thymine, respectively (Vogels \& van der Drift, 1976). The presence of the pyrimidine reductive catabolic pathway in $P$. aeruginosa and $\boldsymbol{P}$. chlororaphis has also been demonstrated (Kim \& West, 1991; West, 1991b).

Dihydropyrimidine dehydrogenase showed maximal activity being with NADH as nicotinamide cofactor. A possible explanation for any dehydrogenase activity being observed using NADPH as a cofactor is likely related to the presence of NAD(P) transhydrogenase (EC 1.6.1.1) in pseudomonad cells (Kaplan, 1955). This enzyme catalyses an essentially irreversible reaction involving the reduction of $\mathrm{NAD}^{+}$by NADPH to synthesize NADH. The NADH formed can be used as substrate for the $P$. stutzeri dehydrogenase. NADH is also the nicotinamide cofactor for dihydropyrimidine dehydrogenase in other pseudomonads (Kim \& West, 1991; West, $1991 a, b$ ).

The three enzymes of the pyrimidine reductive catabolic pathway in P. stutzeri were affected by growth conditions. Dihydropyrimidine dehydrogenase activity was increased after growth on pyrimidine bases as nitrogen sources. Growth on either pyrimidine or dihydropyrimidine bases increased the levels of dihydropyrimidinase and $N$-carbamoyl- $\beta$-alanine amidohydrolase. Dihydropyrimidinase activity was highly increased after growth on dihydrothymine while the dihydropyrimidine bases increased amidohydrolase activity. Carbon source influenced dihydropyrimidine dehydrogenase and dihydropyrimidinase levels in $P$. stutzeri in a fashion that was still dependent upon nitrogen source. In $P$. aeruginosa, the three pyrimidine reductive catabolic pathway enzymes were induced at least twofold only by uracil (Kim \& West, 1991). In this study, it was demonstrated that the three pathway enzymes could be induced severalfold by thymine. Growth on pyrimidines and dihydropyrimidines has been shown to affect the pyrimidine reductive catabolic enzymes in other pseudomonads. In $P$. pseudoalcaligenes, cytosine, uracil, thymine or dihydrothymine as nitrogen source increased dihydropyrimidine dehydrogenase activity, while dihydropyrimidinase activity was increased by the abovementioned nitrogen sources as well as by dihydrothymine (West, 1991 a). In P. chlororaphis, the nitrogen sources uracil, dihydrouracil, thymine and dihydrothymine increased dihydropyrimidine dehydrogenase activity. With respect to dihydropyrimidinase activity in $P$. chlororaphis, growth on the nitrogen source dihydrothymine resulted in over a 100 -fold increase in activity (West, 1991b). Uracil and dihydrouracil also produced an elevation in dihydropyrimidinase activity but to a lesser extent than dihydrothymine (West, 1991b). Dihydropyrimidinase activity has also been detected in Pseudomonas putida (Takahashi et al., 1978; Sun, 1983; Chevalier et al., 1989). In this pseudomonad, it has been shown that growth on uracil (Sun, 1983), but not growth 
on dihydrouracil (Morin et al., 1986), induced dihydropyrimidinase activity.

In conclusion, this work indicates that pyrimidine bases are degraded reductively in $P$. stutzeri. The reductive pathway enzymes are greatly affected by growth on pyrimidines and dihydropyrimidines as nitrogen sources. Moreover, the rise in activity of these catabolic enzymes is dependent on protein synthesis, indicating that the syntheses of these enzymes are inducible.

Published with the approval of the Director of the South Dakota Agricultural Experiment Station as Publication 2649 of the Journal Series.

\section{References}

BradFord, M. M. (1976). A rapid and sensitive method for the quantitation of microgram quantities of protein utilizing the principle of dye-binding. Analytical Biochemistry 72, 248-254.

CAMPBELL, L. L., JR (1957). Reductive degradation of pyrimidines. II. Mechanism of uracil degradation by Clostridium uracilicum. Journal of Bacteriology 73, 225-229.

Chevalier, P., Roy, D. \& Morin, A. (1989). Hydantoinase activity of immobilized non-growing Pseudomonas putida cells. Applied Microbiology and Biotechnology 30, 482-486.

HAYAISHI, O. \& KORNBERG, A. (1952). Metabolism of cytosine, thymine, uracil, and barbituric acid by bacterial enzymes. Journal of Biological Chemistry 197, 717-732.

HunNinghake, D. \& GRISOliA, S. (1965). Uracil and thymine reductases. Methods in Enzymology 12A, 50-59.

KaPLAN, N. O. (1955). Pyridine nucleotide transhydrogenase. Methods in Enzymology 2, 681-687.

KIM, S. \& WeST, T. P. (1991). Pyrimidine catabolism in Pseudomonas aeruginosa. FEMS Microbiology Letters 77, 175-180.
KRAMER, J. \& KALTWASSER, H. (1969). Verwertung von pyrimidinderivaten durch Hydrogenomonas facilis. I. Intermediarprodukte und enzyme des cytosinabbaues. Archiv für Mikrobiologie 68, 227-235.

LARA, F. J. S. (1952). On the decomposition of pyrimidines by bacteria I. Studies by means of the technique of simultaneous adaption. Journal of Bacteriology 64, 271-277.

Morin, A., Hummel, W. \& Kula, M.-R. (1986). Production of hydantoinase from Pseudomonas fluorescens strain DSM 84. Applied Microbiology and Biotechnology 25, 91-96.

PATEL, B. N. \& WeST, T. P. (1987). Oxidative catabolism of uracil by Enterobacter aerogenes. FEMS Microbiology Letters 40, 33-36.

Stanier, R. Y., Palleroni, N. J. \& Doudoroff, M. (1966). The aerobic pseudomonads: a taxonomic study. Journal of General Microbiology 43, 159-271.

SuN, W. (1983). Screening of strains producing dihydropyrimidinase and fermentation conditions. Weishengwu Xuebao 23, 133-142.

TakaHashi, S., KiI, Y., Kumagai, H. \& Yamada, H. (1978). Purification, crystallization and properties of hydantoinase from Pseudomonas striata. Journal of Fermentation Technology 56, 492-498.

TAMaki, N. \& MizUTANI, N. (1987). Purification and properties of $\beta$ ureidopropionase from the rat liver. European Journal of Biochemistry 169, 21-26.

VoGELS, G. D. \& VAN DER DRIFT, C. (1976). Degradation of purines and pyrimidines by microorganisms. Bacteriological Reviews 40, 403468.

WEST, T. P. (1989). Isolation and characterization of thymidylate synthetase mutants of Xanthomomas maltophilia. Archives of Microbiology 151, 220-222.

WEST, T. P. (1991 a). Pyrimidine base and ribonucleoside utilization of the Pseudomonas alcaligenes group. Antonie van Leeuwenhoek 59, 263268.

WEST, T. P. (1991 b). Isolation and characterization of a dihydropyrimidine dehydrogenase mutant of Pseudomonas chlororaphis. Archives of Microbiology 156, 513-516.

West, T. P., Shanley, M. S. \& O’Donovan, G. A. (1982). Improved colorimetric procedure for quantitating $N$-carbamoyl- $\beta$-alanine with minimum dihydrouracil interference. Analytical Biochemistry 122 345-347.

West, T. P., Traut, T. W., Shanley, M. S. \& O’Donovan, G. A (1985). A Salmonella typhimurium strain defective in uracil catabolism and $\beta$-alanine synthesis. Journal of General Microbiology 131, 1083-1090. 